\title{
STUDI KORELASI ANTARA PEMAHAMAN MATEMATIS DENGAN PRESTASI BELAJAR TARUNA AKADEMI MARITIM NUSANTARA PADA MATAKULIAH DASAR-DASAR AKUNTANSI
}

\author{
Luthfiana Tarida $^{1 *}$, Indriyani ${ }^{2}$, V.Budi Sampurno ${ }^{2}$ \\ ${ }^{1}$ Program studi Nautika, AMN Cilacap \\ Jl.Kendeng No.307, Sidanegara, Cilacap. \\ ${ }^{2}$ Program studi Ketatalaksanaan Pelayaran Niaga dan Kepelabuhanan, AMN Cilacap \\ Jl.Kendeng No.307, Sidanegara, Cilacap. \\ "Email: luthfianatarida@amn.ac.id
}

\begin{abstract}
Abstrak
Pengetahuan akuntansi menjadi landasan dalam membuka jasa pelayaran, sehingga dapat meminimalkan kerugian, misal dalam membuat budgeting plan, dan forcasting, manajemen gudang dan bongkar muat. Oleh karena itu, Akuntansi menjadi matakuliah wajib pada kurikulum Program Studi Ketatalaksanaan Pelayaran Niaga dan Kepelabuhanan (KPN) Akademi Maritim Nusantara (AMN). Matakuliah yang memiliki kesamaan karakteristik dengan dasar-dasar akuntansi adalah matematika. Pemahaman matematis diduga memberikan pengaruh terhadap prestasi belajar dasar-dasar akuntansi. Oleh karena itu, penelitian ini bertujuan menganalisis pengaruh pemahaman matematis terhadap prestasi belajar taruna AMN pada matakuliah dasar-dasar akuntansi. Jenis penelitian ini merupakan penelitian kuantitatif dengan dengan sampel 146 taruna angkatan 2018 KPN AMN. Metode pengumpulan data dilakukan melalui instrumen tes Metode analisis data menggunakan statistik deskriptif dan statistik inferensial berbantuan aplikasi SPSS taraf signifikansi 0,05. Statistik inferensial terdiri dari uji asumsi klasik dan uji analisis regresi. Sebelum melakukan uji analisis regresi, harus terpenuhi uji asumsi klasik, yang terdiri dari uji normalitas, linearitas, dan homokedasitas. Hasil penelitian yaitu terdapat pengaruh yang signifikan antara pemahaman matematis dengan prestasi belajar taruna AMN pada matakuliah dasar-dasar akuntansi. Setiap kenaikan pemahaman matematis 1\%, maka prestasi belajar taruna AMN pada matakuliah dasar-dasar akuntansi meningkat sebesar 1,004\%. Semakin tinggi pemahaman matematis taruna AMN, maka akan semakin tinggi prestasi belajar dasar-dasar akuntansi.
\end{abstract}

Kata kunci: matematika, akuntansi, taruna AMN, pengaruh, prestasi

\section{PENDAHULUAN}

Matakuliah Dasar-dasar Akuntansi merupakan matakuliah wajib yang terdapat pada kurikulum Program Studi Ketatalaksanaan Pelayaran Niaga dan Kepelabuhanan (KPN) di Akademi Maritim Nusantara (AMN). Penyusunan kurikulum didasarkan pada standar nasional. Matakuliah Dasar-dasar Akuntansi penting untuk dipelajari karena merupakan prasyarat matakuliah-matakuliah lain di semester berikutnya, seperti matakuliah Akuntansi dan Pembelanjaan Perusahaan Pelayaran I dan II. Penguasaan matakuliah tersebut dapat dijadikan bekal oleh taruna untuk bersaing di dunia kerja. Hal ini sesuai dengan prospek kerja lulusan Program Studi KPN yang memiliki peluang besar bekerja di Perusahaan Pelayaran, seperti Perusahaan Jasa Kepabeanan, Ekspedisi dan Perusahaan Ship's Management Perusahaan Marine Insurance \& Claim.

Hasil wawancara dengan alumni Program Studi KPN AMN, menyatakan bahwa selama bekerja di perusahaan pelayaran, basic akuntansi penting dikuasi, misal dalam membuat budgeting plan, dan forcasting, manajemen gudang dan bongkar muat. Pengetahuan akuntansi menjadi landasan untuk membuka jasa pelayaran, sehingga dapat meminimalkan kerugian. Penguasaan akuntansi dapat meningkatkan kemampuan berpikir kritis sehingga dapat menyelesaiakan permasalahan yang dihadapi.

Matakuliah yang memiliki kesamaan karakteristik dengan dasar-dasar akuntansi adalah matematika. Beberapa kesamaan antara matematika dan akuntansi yaitu menekankan penggunaan logika, 
penggunaan simbol, dan memiliki rumusrumus pasti. Jadi, besar kemungkinan jika seorang taruna yang kemampuan matematikanya bagus, maka kemampuan akuntasinya juga bagus. Menurut beberapa penelitian terdahulu yang dilakukan oleh Dian Mardiyant, Handayani Dwi Nita, dan Ermawati, menyatakan bahwa ada pengaruh antara kemampuan matematika terhadap kemampuan akuntansi (Fajriah \& Mastum, 2015).

Akuntansi juga menggunakan logika matematika. Akuntansi sebagai suatu seni yang mendasarkan pada logika matematik sekarang dikenal sebagai "pembukuan berpasangan". Adapun contoh logika pada akuntansi adalah pada perhitungan laba kotor (Fajriah \& Mastum, 2015). Hal ini sangat memungkinkan adanya pengaruh dari pemahaman matematis terhadap prestasi belajar akuntansi taruna AMN.

Taruna dalam mempelajari matematika dan dasar-dasar akuntansi memerlukan ketelitian, melibatkan perhitungan, penalaran, pemecahan masalah yang bersifat sistematis dan bertahap. Kritzer menyatakan hal serupa, matematika merupakan gabungan dari pemecahan masalah, penalaran dan pembuktian, komunikasi, membuat koneksi, dan menggunakan representasi (Afridiani et al., 2020).

Matematika dan dasar-dasar akuntansi menjadi matakuliah yang dirasa sulit dipahami oleh taruna. Rendahnya prestasi belajar dalam matematika juga merupakan sebuah kenyataan yang ada di masyarakat (Herawati, 2016). Berdasarkan survei, rata-rata nilai matematika dan dasardasar akuntansi taruna di AMN cukup rendah. Rata-rata nilai matematika dan dasar-dasar akuntansi taruna AMN angkatan 2018, masing-masing sebesar 62,5 dan 53 dari nilai maksimal 100. Padahal kedua matakuliah tersebut penting untuk dipelajari karena menjadi prasyarat untuk matakuliah di semester selanjutnya. Pada lapangan pekerjaan yang berkaitan dengan Ketatalaksanaan Pelayaran Niaga dan
Kepelabuhan juga dibutuhkan keahlian individu dalam perhitungan akuntansi.

Rendahnya rata-rata nilai matakuliah matematika dan dasar-dasar akuntansi berbanding terbalik dengan tolak ukur keberhasilan pembelajaran. Pembelajaran yang baik adalah usaha yang berhasil membawa taruna kepada tujuan yang ingin dicapai yaitu agar materi pembelajaran yang disampaikan dapat dipahami sepenuhnya oleh taruna (Cahyani et al., 2018).

Kemampuan pemahaman matematis merupakan kemampuan yang sangat penting untuk menunjang keberhasilan pembelajaran. (Sinaga, 2018). Keberhasilan pembelajaran erat kaitannya dengan prestasi belajar. Azwar berpendapat bahwa "Prestasi belajar adalah performansi maksimal subjek dalam menguasai bahan-bahan atau materi yang diajarkan" (Sumaryati \& Ulfa, 2016). Kemampuan taruna dalam menyerap dan memahami materi dasar-dasar akuntansi dapat diketahui melalui prestasi belajarnya. Prestasi belajar diperoleh dengan penilaian setelah proses pembelajaran selesai.

Pada prinsipnya banyak ahli yang setuju bahwa prestasi belajar dipengaruhi oleh dua faktor yaitu internal dan eksternal. Menurut Slameto, faktor internal yaitu faktor yang ada dalam diri individu yang sedang belajar, sedangkan faktor eksternal yaitu faktor dari luar individu (Pradhana \& Latifah, 2013).

Penelitian sebelumnya diperoleh simpulan bahwa terdapat pengaruh yang positif baik secara parsial maupun simultan antara penguasaan kosa kata bahasa Inggris, dasar komputer dan akuntansi dasar terhadap prestasi belajar komputer akuntansi MYOB kelas XI KK Akuntansi SMK Negeri 1 Bawang Kabupaten Banjarnegara tahun ajaran 2011/2012 (Pradhana \& Latifah, 2013). Penguasaan kosa kata bahasa Inggris, dasar komputer dan akuntasi merupakan faktor intern yang dimiliki siswa dalam mendukung prestasi belajar komputer akuntansi MYOB. Hal ini melandasi tujuan penelitian ini, yaitu menganalisis pengaruh pemahaman 
matematis terhadap prestasi belajar taruna AMN pada matakuliah dasar-dasar akuntansi.

\section{LANDASAN TEORI \\ Pemahaman Matematis}

Matematika merupakan salah satu ilmu pendidikan yang memerlukan pikiran untuk memahami, mengingat serta mengenal tentang

aturan-aturan yang sudah ada dan harus dipatuhi guna menguasai materi yang akan dipelajari (Afridiani et al., 2020). Pemahaman matematis merupakan kemampuan taruna dalam menyelesaiakan permasalahan matematis pada matakuliah Matematika.

\section{Prestasi Belajar Dasar-Dasar Akuntansi}

Materi akuntansi dasar meliputi akuntansi perusahaan jasa dan perusahaan dagang. Pada awal materi dipaparkan tentang definisi akuntansi, pengguna informasi keuangan, dan dilanjutkan siklus akuntansi perusahaan jasa dan dagang.(Pradhana \& Latifah, 2013). Menurut American Accounting Association, dasar-dasar Akuntansi adalah proses mengidentifikasi, mengukur, dan melaporkan informasi ekonomi untuk memungkinkan adanya penilaian dan pengambilan keputusan yang jelas dan tegas bagi mereka yang menggunakan informasi keuangan ter- sebut (Santoso, 2012) (Sumaryati \& Ulfa, 2016). Selain dilakukan secara sistematis dan bertahap, dalam memahami dan mempelajari akuntansi (akuntansi dasar) juga diperlukan ketekunan dan ketelitian (Fachrurrozie, 2010).

Prestasi belajar merupakan hasil dari pengukuran terhadap peserta didik yang meliputi faktor kognitif, afektif dan psikomotor setelah mengikuti proses pembelajaran yang diukur dengan menggunakan instrumen tes yang relevan (Pradhana \& Latifah, 2013). Jadi prestasi belajar taruna pada matakuliah dasar-dasar akuntansi dapat diartikan sebagai hasil pengukuran instrumen tes meliputi faktor kognitif, afektif dan psikomotor setelah taruna mengikuti proses pembelajaran matakuliah dasar-dasar akuntansi selama satu semester.

\section{METODE}

Jenis penelitian ini merupakan penelitian kuantitatif dengan populasi taruna Program Studi KPN di AMN. Berdasarkan teknik pengambilan sampel, probability sampling, diperoleh sampel 146 taruna angkatan 2018 Program Studi KPN AMN.

Variabel dependen pada penelitian ini yaitu prestasi belajar taruna AMN pada matakuliah dasar-dasar akuntansi. Varibel indenpenden berupa kemampuan pemahaman matematis taruna AMN. Metode pengumpulan data dilakukan melalui instrumen tes untuk kedua variabel.

Metode analisis data menggunakan statistik deskriptif dan statistik inferensial berbantuan aplikasi SPSS menggunakan taraf signifikansi 0,05 . Statistik inferensial terdiri dari uji asumsi klasik dan uji analisis regresi. Sebelum melakukan uji analisis regresi, harus terpenuhi uji asumsi klasik, yang terdiri dari uji normalitas, linearitas, dan homokedasitas (Budiyono, 2015). Jadi uji regresi hanya dapat dilakukan jika: (1) pada uji normalitas, data yang digunakan dalam penelitian memenuhi syarat berdistribusi normal; (2) pada uji linearitas, terdapat hubungan linear secara signifikan antara pemahaman matematis dengan prestasi belajar dasar-dasar akuntansi; (3) pada uji homokedasitas, variasi prestasi belajar dasar-dasar akuntansi di sekitar garis regresi harus konstan untuk setiap pemahaman matematis (Indriyani \& Tarida, 2020).

Simpulan penelitian sebelumnya menyatakkan terdapat pengaruh yang positif ntara penguasaan kosa kata bahasa Inggris, dasar komputer dan akuntansi dasar terhadap prestasi belajar komputer akuntansi MYOB (Pradhana \& Latifah, 2013). Penguasaan kosa kata bahasa Inggris, dasar komputer dan akuntasi merupakan faktor intern yang dimiliki 
siswa dalam mendukung prestasi belajar komputer akuntansi MYOB. Kemampuan pemahaman matematis tergolong dalam faktor intern yang mempengaruhi prestasi belajar. Menurut Fachrurrozie (2010), pencapaian prestasi belajar dapat maksimal apabila faktor-faktor yang mempengaruhi prestasi belajar mahasiswa tersebut diupayakan maksimal pula. Kemampuan pemahaman matematis yang maksimal diduga kuat berpengaruh terhadap prestasi belajar dasar-dasar akuntansi yang maksimal. Berdasarkan kerangka berpikir teeoritis tersebut, disusun hipotesis pada uji regresi:

$\mathrm{H}_{0}$ : Tidak ada pengaruh yang signifikan antara pemahaman matematis dengan prestasi belajar taruna AMN pada matakuliah dasar-dasar akuntansi

$\mathrm{H}_{\mathrm{a}}$ : Terdapat pengaruh yang signifikan antara pemahaman matematis dengan prestasi belajar taruna AMN pada matakuliah dasar-dasar akuntansi

Persamaan analisis regresi dirumuskan:

$$
Y=a+\beta X
$$

$Y$ : Prestasi belajar taruna AMN pada matakuliah dasar-dasar akuntansi

$X$ : Pemahaman matematis taruna AMN

\section{HASIL DAN PEMBAHASAN}

\section{Uji Normalitas}

Uji normalitas dilakukan menggunakan

One Sample Kolmogorov-Smirnov Test dengan bantuan program SPSS. Hasil uji normalitas dirangkum dalam tabel 1 .

\section{Tabel 1. Rangkuman Hasil Uji} Normalitas Data Penelitian

\begin{tabular}{|l|c|c|}
\hline $\begin{array}{c}\text { One-Sample } \\
\text { Kolmogorov- } \\
\text { Smirnov Test }\end{array}$ & $\begin{array}{c}\text { Kolmogo } \\
\text { rov- } \\
\text { Smirnov }\end{array}$ & $\begin{array}{c}\text { Asymp. } \\
\text { Sig. (2- } \\
\text { tailed) }\end{array}$ \\
\hline $\begin{array}{l}\text { Residual dari X } \\
\text { dan Y }\end{array}$ & 0,724 & 0,670 \\
\hline
\end{tabular}

Sumber: Data diolah Penulis, 2021

Berdasarkan tabel diperoleh nilai Asymp.Sig. $(2-$ tailed $)=0,067>0,05$, sehingga diperoleh kesimpulan data pemahaman matematis dan prestasi belajar dasar-dasar akuntansi berdistribusi normal. Artinya, data menyebar secara normal mengikuti persamaan regresi. Tidak terdapat data pencilan yang distribusinya jauh dari persamaan regresi. Syarat normalitas untuk uji regresi terpenuhi.

\section{Uji Linearitas}

Uji linearitas menggunakan Test for Linearity dengan bantuan program SPSS. Uji linearitas bertujuan untuk menganalisis ada tidaknya hubungan linear secara signifikan antara variabel $\mathrm{X}$ dan Y. Hasil uji linearitas yang muncul pada Output SPSS Tabel Anova dirangkum dalam tabel 2.

Tabel 2. Rangkuman Hasil Uji Linearitas
\begin{tabular}{|l|c|c|}
\hline Data Penelitian \\
\hline Variabel & $\begin{array}{c}\text { Deviation for } \\
\text { Linearity Sig. }\end{array}$ & Keterangan \\
\hline $\begin{array}{l}\text { X } \\
\text { dengan } \\
\text { Y }\end{array}$ & 0,447 & $\begin{array}{c}\text { Ada } \\
\text { hubungan } \\
\text { linear }\end{array}$ \\
\hline
\end{tabular}

Sumber: Data diolah Penulis, 2021

Berdasarkan tabel 2 diperoleh nilai Deviation for Linearity Sig. 0,447 >

0,05 sehingga disimpulkan terdapat hubungan linear antara pemahaman matematis dan prestasi belajar dasar-dasar akuntansi. Jadi pemahaman matematis dan prestasi belajar dasar-dasar akuntansi berada pada satu jalur yang sebidang/ memiliki kesamaan karakteristik yang saling berhubungan. Syarat linearitas untuk uji regresi terpenuhi.

\section{Uji Homokedasitas}

Uji homokedasitas dilakukan menggunakan uji Glejser dengan bantuan SPSS. Rangkuman hasil uji homokedasitas dapat dilihat pada tabel 3 .

Tabel 3. Rangkuman Hasil Uji Homokedasitas Data Penelitian

\begin{tabular}{|l|c|c|}
\hline Variabel & T & Sig. \\
\hline $\mathrm{X}$ & $-1,276$ & 0,204 \\
\hline $\mathrm{Y}$ & 1,842 & 0,068 \\
\hline
\end{tabular}

Sumber: Data diolah Penulis, 2021 
Berdasarkan Tabel 3, diperoleh nilai Sig. 0,204 $>0,05$ untuk variabel $\mathrm{X}$ dan Sig. 0,068 $>0,05$ untuk variabel $\mathrm{Y}$ yang berarti tidak terjadi gejala heterokedasitas. Jadi hasil pengamatan variasi pemahaman matematis untuk setiap prestasi belajar dasar-dasar akuntansi bernilai tetap dari satu pengamatan ke pengamatan lain. Syarat homokedasitas terpenuhi untuk uji regresi.

\section{Uji Regresi}

Uji regresi linear sederhana dilakukan dengan bantuan SPSS. Tabel 4 berikut menginformasikan hasil uji $\mathrm{T}$ pada regresi linear sederhana.

\section{Tabel 4. Rangkuman Hasil Uji T}

\begin{tabular}{|l|c|c|c|c|}
\hline \multirow{2}{*}{ Model } & \multicolumn{2}{|c|}{$\begin{array}{c}\text { Unstandardized } \\
\text { Coefficients }\end{array}$} & \multirow{2}{*}{$\mathrm{T}$} & \multirow{2}{*}{ Sig. } \\
\cline { 2 - 4 } & $\mathrm{B}$ & $\begin{array}{c}\text { Std. } \\
\text { Error }\end{array}$ & & \\
\hline $\begin{array}{l}\text { (Cons- } \\
\text { tant) }\end{array}$ & $-9,761$ & 10,485 & $-0,931$ & 0,353 \\
\hline $\mathrm{X}$ & 1,004 & 0,167 & 6,024 & 0,000 \\
\hline
\end{tabular}

Sumber: Data diolah Penulis, 2021

Berdasarkan Tabel 4, diperoleh nilai Sig. 0,000 < 0,05, $\mathrm{H}_{0}$ ditolak. Jadi terdapat pengaruh yang signifikan antara pemahaman matematis dengan prestasi belajar taruna AMN pada matakuliah dasardasar akuntansi dengan persamaan regresi sebagai berikut:

$$
Y=-9,761+1,004 X
$$

Nilai koefisien regresi pemahaman matematis berpengaruh positif terhadap prestasi belajar taruna AMN pada matakuliah dasar-dasar akuntansi sebesar 1,004. Jadi setiap kenaikan pemahaman matematis $1 \%$, maka prestasi belajar taruna AMN pada matakuliah dasar-dasar akuntansi meningkat sebesar $1,004 \%$. Semakin tinggi pemahaman matematis taruna AMN, maka akan semakin tinggi prestasi belajar dasar-dasar akuntansi.

Simpulan dari penelitian ini, didukung beberapa penelitian relevan sebelumnya. Wibawa (2015) dan Monicca et al., (2015) dalam penelitiannya menyatakan kemampuan matematika menjadi salah satu faktor internal yang mempengaruhi prestasi belajar akuntansi pada siswa SMK. Perbedaan kemampuan matematika yang dimiliki akan berpengaruh terhadap prestasi belajar akuntansi yang berbeda pula. Jadi kemampuan matematika yang rendah pada siswa dapat menyebabkan kurang dalam kemampuan akuntansinya, sebab dalam belajar akuntansi terdapat perhitungan-perhitungan yang dipelajari dalam matematika seperti penjumlahan, pengurangan, perkalian, dan pembagian (Fajriah \& Mastum, 2015).

Penguasaan terhadap akuntansi bagi lulusan Program Studi KPN sangat besar konstribusinya, terutama pada bidang kerja. Terdapat banyak manfaat dari akuntansi, di antaranya dalam pengaturan sistem informasi akuntansi retribusi boarding pass pelabuhan yang nantinya dapat berpengaruh terhadap sistem pengendalian internal suatu pelabuhan (Karmila \& Hendarsyah, 2019).

\section{KESIMPULAN}

Berdasarkan analisis data dan kajian teoritis, diperoleh kesimpulan bahwa pemahaman matematis berpengaruh positif terhadap prestasi belajar taruna AMN pada matakuliah dasar-dasar akuntansi. Oleh karena itu, dibutuhkan pembelajaran yang dapat mendukung perolehan pemahaman matematis yang maksimal, sehingga prestasi belajar taruna AMN pada matakuliah dasar-dasar akuntansi juga maksimal.

\section{DAFTAR PUSTAKA}

Afridiani, T., Soro, S., \& Faradillah, A., 2020, Pengaruh Model Problem Based Learning (PBL) Berbasis Lembar Kerja Peserta Didik (LKPD) Terhadap Kemampuan Pemahaman Konsep Matematis, Euclid, Vol. 7, No. 1 ,

Cahyani, E. P., Wulandari, W. D., Rohaeti, E. E., \& Fitrianna, A. Y., 2018, Hubungan Antara Minat Belajar Dan Resiliensi Matematis Terhadap Kemampuan Pemahaman Matematis 
Siswa Kelas VIII Smp, Jurnal Numeracy, Vol. 5, No. 1, pp. 49-56.

Fachrurrozie, 2010, Efektifitas Peta Konsep

Dalam Pembelajaran Mata Kuliah

Dasar Akuntansi, Dinamika

Pendidikan Unnes, Vol. 5, No. 2, pp. 165-179.

Fajriah, A. N., \& Mastum, J. H., 2015, Pengaruh Hasil belajar Matematika Terhadap Hasil Belajar Akuntansi Siswa di SMK, Jurnal Pendidikan Dan Pembelajaran Khatulistiwa, Vol. 4, No. 3, pp. 1-13.

Herawati, L.,2016, Pembelajaran Melalui Strategi REACT untuk Meningkatkan Kemampuan Pemahaman Matematis Siswa Sekolah Menengah Kejuruan, Jurnal Penelitian Pendidikan Dan Pengajaran Matematika, Vol. 2, No. 1, pp. 35-40.

Karmila, K., \& Hendarsyah, D., 2019, Pengaruh Sistem Informasi Akuntansi Retribusi Boarding Pass Pelabuhan Terhadap Sistem Pengendalian Internal: Studi Pada PT. Pelabuhan Indonesia I (Persero) Cabang Dumai, JAS (Jurnal Akuntansi Syariah), Vol. 3, No. 2, pp.158-173.

Monicca, I., Subkhan, \& Setiyani, R., 2015, Pengaruh Minat Belajar, Motivasi
Belajar Dan Prestasi Belajar Matematika Terhadap Prestasi Belajar Akuntansi Siswa Kelas X Jurusan Akuntansi Di Smk Palebon Semarang, Economic Education Analysis Journal, Vol. 4, No. 2, pp. 414-426.

Pradhana, D. Y., \& Latifah, L., 2013, Pengaruh Kosa Kata Bahasa Inggris, Dasar Komputer Dan Akuntansi Terhadap Prestasi Belajar Myob. Dinamika Pendidikan, Vol. 8, No. 2, pp. 75-84.

Sinaga, N., 2018, Penerapan Pembelajaran Matematika Realistik untuk Mningkatkan Kemampuan Pemahaman Matematis Siswa pada Materi Bentuk Aljabar di Kelas VII $S M P$, Jurnal Pendidikan Mateatika, Vol. 1, No. 1, pp. 25-35.

Sumaryati, S., \& Ulfa, F., 2016, DasarDasar Akuntansi Melalui Penerapan Model Jigsaw, At Tarbawi, Vol. 1, No. 1, pp. 24-38.

Wibawa, R., 2015, Pengaruh Strategi Pembelajaran dan Kemampuan Matematika terhadap Hasil Belajar Akuntansi, Jurnal Paedagogy, Vol. 2 No. 1, pp. 36-47. 